\title{
Studies on corrosion resistant properties of inhibitive primed IPN coating systems in comparison with epoxy-PU systems
}

\author{
S. M. Krishnan, P. S. Mohan
}

(C) FSCT and OCCA 2008

Erratum to: J. Coat. Technol. Res. (2007) 4(1): 89-100

\section{DOI 10.1007/s11998-007-9004-5}

In the March issue of Journal of Coatings Technology and Research [4, (1) 89-100 (2007)], the authors reference a "QUV Weather-Ometer test." QUV, a registered trademark of Q-Lab Corporation, is a weathering testing device that uses eight fluorescent bulbs. Weather-Ometer ${ }^{\circledR}$ is a registered trademark of Atlas Material Testing Technology LLC. This weathering device uses a xenon arc light source. The studies referenced in the article used the QUV device. We apologize for the error-Ed.

The online version of the original article can be found under doi:10.1007/s11998-007-9004-5.

S. M. Krishnan ( $₫)$, P. S. Mohan

Central Electrochemical Research Institute,

Karaikudi 630 006, India

e-mail: fiftysmk@yahoo.com 